\title{
UV-B Radiation as a Factor that Deserves Further Research in Bolivian Viticulture: A Review
}

\author{
G. Gutiérrez-Gamboa ${ }^{1}$, P. Pszczólkowski ${ }^{1, *}$, P. Cañón ${ }^{1}$, M. Taquichiri² J. M. Peñarrieta ${ }^{3, *}$ \\ (1) Escuela de Agronomía, Facultad de Ciencias, Universidad Mayor, Chile, Huechuraba, Chile. \\ (2) Physics Department, Faculty of Science and Technology, Universidad Autónoma Juan Misael Saracho, Tarija, Bolivia \\ (3) School of Chemistry, Faculty of Pure and Natural Sciences, Universidad Mayor de San Andrés (UMSA), La Paz, Bolivia.
}

Submitted for publication: June 2021

Accepted for publication: September 2021

Keywords: Andean viticulture, amino acids, high-altitude vineyards, phenolic compounds, resveratrol, Tarija Valley, UV radiation

\begin{abstract}
Bolivian viticulture has acquired an incipient notoriety in the international wine market due to the production of high-altitude wines with a high antioxidant potential. Andes agricultural regions present an advantage for wine production since UV-B radiation reaching the earth's surface increases with altitude and varies with latitude, promoting the activation of plant defense mechanisms responsible for the synthesis of secondary metabolites. UV-B radiation upregulates the biosynthesis of nitrogen, phenolic and volatile compounds that contribute to wine flavour. It is thought that the incident UV-B radiation in the Bolivian valleys makes it possible to obtain wines with high phenolic and aromatic potential, but the published results are not entirely conclusive. This manuscript addressed the geological and climatic features that affect Bolivian viticulture, and we reviewed the field studies carried out regarding the effects of altitude and UV-B radiation on flavour components of grapes and wines from Bolivian viticultural valleys. A high antioxidant capacity and trans-resveratrol content is found in grapes and wines from highaltitude Bolivian vineyards, including if they are compared to those samples from different wine countries. However, high UV-B radiation can result in bunch sunburn affecting some physico-chemical parameters of the produced wines. Scarce number of studies have been developed in this field despite this region present a valuable potential for research in order to quantify the effects of biologically damaging radiation on the synthesis of flavour components in grapes and some of them were not well scientifically controlled.
\end{abstract}

\section{INTRODUCTION}

Currently, viticulture is an important activity of the agriculture in many regions of Andean America (Preston \& Clewer, 1993). In 1960, the introduction of new genetic material and production technologies were prioritized in order to intensify and modernize the viticulture sector (Turner \& Davidson-Hunt, 2016). The reconfiguration of the regional economy towards viticulture was consolidated during the 1990s through continued capital investment, the establishment of education, a plant nursery and research facilities (Turner \& Davidson-Hunt, 2016). These important efforts have resulted in the establishment of the spirit Singani as a typical beverage of this region by origin denomination and the famous of wines produced from grapes from highaltitude vineyards to the international wine market to this day.

The total surface area of the vineyards planted in Bolivia is estimated at 2,500 ha of which $65 \%$ is located in the Central Valley of Tarija (Pszczólkowski et al., 2010), whose wine ecosystem has production limitations due to complex pedoclimatic conditions (Aguilar \& Pszczólkowski, 2012).
Bolivia's sub-equatorial and inter Andean valleys are located mainly at the end of the Andean mountain range which have elevations of between 2,000-4,000 metres above sea level (m. a. s. 1.), and latitudes in the range of $10^{\circ}-20^{\circ}$ South (Taquichiri et al., 2014). Bolivian viticulture is mostly located at 1,660 to 2,360 m. a. s. 1. (Pszczólkowski et al., 2010). Based upon latitude and altitude, Bolivian viticulture could be defined as a subtropical, corresponding to a cool semi-arid zone based on Köppen classification, with a large mesoclimatic variability (Pszczólkowski et al., 2010).

The viticultural regions of Tarija and the Loayza Province of $\mathrm{La}$ Paz receive more intense solar UV radiation is more intense than other places in Bolivia where grapevines are cultivated (Taquichiri et al., 2014). UV-B environmental levels are mainly regulated by cloudiness, season and latitude, but also increase with altitude as UV-B passes through a thinner atmosphere to reach the earth's surface (McKenzie et al., 2007). There are many studies demonstrating that UV radiation reaching the earth's surface increases with altitude and varies with latitude (Zaratti et al., 2003; Pfeifer et al., 
2006). Concerning latitude, UV levels are higher closer to the equator since the sun's rays have a shorter distance to travel through the atmosphere and therefore less of the harmful UV radiation can be absorbed (WHO, 2016). At increasing altitude, less atmosphere is available to absorb UV radiation and, with every $1,000 \mathrm{~m}$ in altitude, UV levels increase by approximately $10 \%$ (WHO 2016). Table grapes are produced at altitudes between 400 to $2,000 \mathrm{~m}$. a. s. 1. in the Chaco Tarijeño, while wine grapes are cultivated between 1,600 and 2,800 m. a. s. 1. in the Valley of Cotagaita (Department of Potosí, Bolivia). Bolivian viticulture therefore lends itself to unique climatic and favourable conditions for the production of grapes and wine with nutritional value listed in Table 1.

Keller \& Torres-Martinez (2004) reported that UV radiation reduced early-season shoot growth but stimulated lateral shoot growth later in the season and enhanced root growth. Concerning plant physiology and grape quality, UV radiation had no obvious effect on leaf chlorophyll and gas exchange, but reduced leaf water content and increased carotenoid and flavonoid concentrations (Keller \& TorresMartinez, 2004). Lafontaine et al. (2005) showed that chlorophyll degradation in leaves and berry skins occurred rapidly in Riesling grapes subjected to high UV-radiation. These authors also reported that exposure of grapes to UV-B radiation increased both the concentration of total bound glycosidic secondary metabolites and phenolics. The synthesis of flavonoid and non-flavonoid compounds in grape skins can increased when grapes are exposed to sunlight (Gregan et al., 2012; Teixeira et al., 2013; Blancquaert et al., 2019). Flavonols are a class of flavonoids with photo-protection activities since they effectively absorb both UV-A and UV-B wavelengths (Flamini et al., 2013). The synthesis of anthocyanins increase in grape skins as a consequence of UV radiation (Berli et al., 2008; CarbonellBejerano et al., 2014). Stilbenes are phytoalexins present in grapes that are associated with health promoting properties (Flamini et al., 2013). Synthesis of some stilbenes can also be induced upon grapevine diseases infection or UV irradiation and accumulation of stilbenes may also be stimulated by the UV received at high altitudes (Pezet et al., 2004; Berli et al., 2011; Carbonell-Bejerano et al., 2014).

Some commercial wine cellars with great purchasing power produce wine from grapes grown at high-altitudes such as Shandong and Yunnan in China, Galilee in Israel and Cafayate and Jujuy in Argentina. Recently, Compés and Sotés (2018) mentioned in their report that in Bolivia, a new viticultural country of surprising interest, and a culture of high-altitude vineyards has developed in the Tarija region. Therefore, Bolivian viticulturists use Criolla and Vinifera cultivars for the production of wine, table grapes and spirits (Gutiérrez-Gamboa et al., 2020). Singani is a controlled designation of origin, which defines the spirits obtained from Moscatel de Alejandría and produced in certain Bolivian areas (Buitrago Soliz, 2014). Singani is considered the national schnapps of Bolivia and is mainly produced in Tarija, the traditional wine-growing region of Bolivia (Buitrago Soliz, 2014; Gutiérrez-Gamboa et al., 2020). This review aims to summarize the effects of altitude on the chemical composition of grapes, i.e. phenolic, volatile and nitrogenous compounds, and to compare altitude impacts with the results obtained under the edaphoclimatic conditions of Bolivian viticulture . It should be noted that there are not many published studies on this geographical area regarding viticultural research. The discussion would compare results from other high-altitude viticultural zones, and discuss the potential impacts under the reality of Bolivian viticulture.

\section{SOIL AND CLIMATE CONDITIONS OF BOLIVIAN VITICULTURE}

\section{Soil conditions}

The Central Valley of Tarija belongs to the geological structure of the Bolivian Cordillera Orientale and its topography is that of a mountainous and hilly border surrounding the catchment area of the Guadalquivir, Tolomosa and Camacho rivers (Pszczólkowski et al., 2010). Tarija soils are frequently and intensely degraded by water and wind erosion (Pszczólkowski et al., 2010). The soil loss values provoked by erosion in Tarija are exorbitantly high, even on nearly level surfaces, amounting to up to 65 metric tons per hectare for a single storm and total losses of approximately of 230 metric tons per ha by year (Bastian \& Gräfe, 1989).

Generally, Tarija soils are characterized by low levels of fertility and organic matter ( $\leq 1 \%$ of OM) (Apaza-Gutiérrez et al., 2002). These soils also have high salinity, sodium toxicity and $\mathrm{pH}$ above 7.5 (Coppus, 2002; Pszczólkowski et al., 2010). Since the presence of sodium carbonate, there are frequent manifestations of black alkalinity symptoms, a situation which makes it difficult for the infiltration of rainwater or irrigation water in soils (Pszczólkowski, 2008). This phenomenon is aggravated by the silty texture and laminar structure of the soils (Pszczólkowski et al., 2010). In addition, these soils have a high level of $\mathrm{Ca}$ and $\mathrm{MgCO}_{3}$, with high contents of active limestone, which promotes iron deficiency (Reyes et al., 2006). The most common rootstocks for grapevines used in Central Valley of Tarija are 99 Richter, 110 Richter and 1003 Paulsen, which tolerate up to $17 \%$ of active limestone, and SO4 rootstock that tolerates close to $20 \%$ of active limestone (Pszczólkowski et al., 2010). Therefore, it is important to evaluate the conditions that result in chlorosis, by measuring certain parameters such as total carbonates (\%), active lime (\%) and CPI (chlorotic power index) (Casanova-Gascón et al., 2018). CPI means that the quantity of active lime is related to the quantity of Fe extracted by ammonium oxalate (Pavlousek, 2013). Rootstocks that presents Vitis berlandieri genetic background are more adapted to calcareous soils than Vitis riparia and Vitis rupestris rootstocks (Pavlousek, 2013). Based on empirical knowledge, the utilization of other rootstocks like Fercal in combination with irrigation, should be evaluated to solve the aforementioned problems (Pszczólkowski et al., 2010).

In Tarija, there is usually a strong soil compaction as a result of the use of mechanization, leading to a limitation of root development by anoxia (Pszczólkowski et al., 2010). Contrary to the vineyards cultivated in Santa Cruz de la Sierra valleys, anoxia problems are present in Tarija vineyards mostly located close to the rivers, due to the presence of a surface water table less than $45 \mathrm{~cm}$ (Pszczólkowski et al., 2010; Aguilar \& Pszczólkowski, 2012).

Seeking new productive solutions, different winemakers 


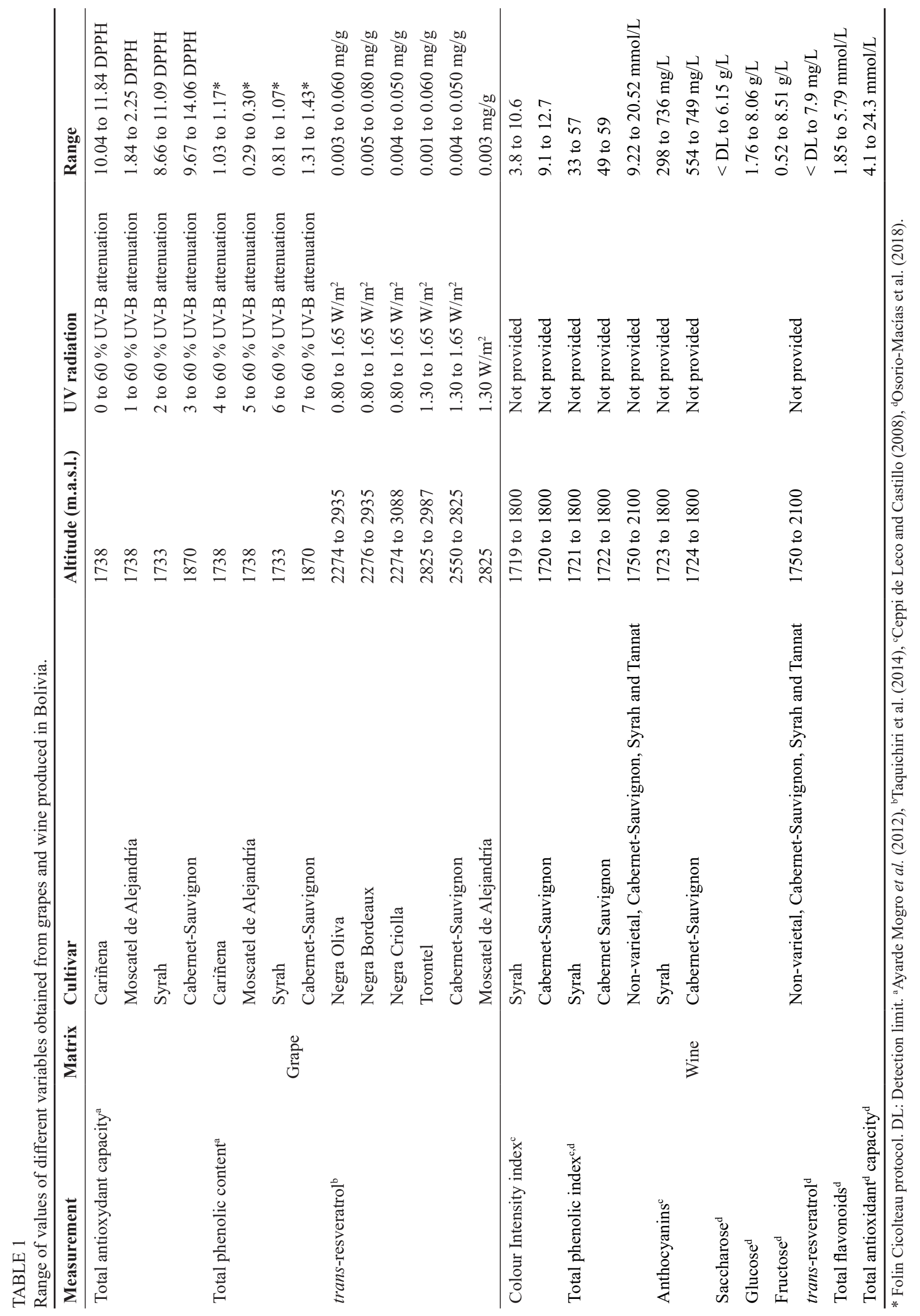


have launched a re-invention of Bolivian viticulture in different ecosystems of the district of Santa Cruz through the planting of small vineyards in mountainous areas, which represents close to 175 ha (Aguilar \& Pszczólkowski, 2012). The soils present in the wine-growing areas of Santa Cruz is of loam-clay texture with a depth that varies from $1.0 \mathrm{~m}$ to $1.5 \mathrm{~m}$, a moderate water holding capacity, and well aerated, which facilitates the infiltration and drainage of water (Aguilar \& Pszczólkowski, 2012). These soils have a low organic matter content reaching less than $1 \%$ (Aguilar \& Pszczólkowski, 2012).

Santa Cruz soils have favourable physicochemical conditions for grapevines (Pszczólkowski et al., 2010; Aguilar \& Pszczólkowski 2012). The soils present low electrical conductivity, low exchangeable sodium percentage and a pH close to 6.8 (Aguilar \& Pszczólkowski, 2012). Regarding soil fertility, Santa Cruz soils exhibit phosphorus deficiency due to the retention of clays and the lack of nitrogen by leaching (Aguilar \& Pszczólkowski, 2012). In addition, the levels of calcium and magnesium carbonates in soils are low and present absence of active limestone substrate, conditions that reduce the risk of ferric chlorosis that affect the initial development of grapevines (Aguilar \& Pszczólkowski, 2012; Gutiérrez-Gamboa et al., 2020; Pszczólkowski et al., 2010). Consequently, Bolivian viticulture is cultivated on diverse types of soils, in terms of physicochemical parameters, such $\mathrm{pH}$, chemical and mineral composition, organic matter and salinity.

\section{Climate conditions}

In the Central Valley of Tarija (Fig. 1), the average maximum temperature ranges from 23.8 (in July) to 27.5 ${ }^{\circ} \mathrm{C}$ (in October or November) and the average minimum temperature ranges from 2.3 (in July) to $14.4^{\circ} \mathrm{C}$ (in January)
(Pszczólkowski et al., 2010). Day-night thermal amplitude is highest in July reaching a difference of $21.5^{\circ} \mathrm{C}$, and lowest in January with an amplitude of $12.7^{\circ} \mathrm{C}$ (Pszczólkowski et al., 2010). The small annual variation in average maximum temperatures is explained by less summer sunshine due to abundant cloudiness and rainfall (November to March), compared to the winter that holds low cloudiness and dryness (Francou et al., 2003; Pszczólkowski et al., 2010).

As in the Central Andes, in the Tarija altiplano and adjacent valleys, $95 \%$ of the annual rainfall falls in spring and summer, specifically between the months of October to April (Preston et al., 2003). During the wet season, rainfall is not evenly distributed, characteristically falling during short, intensive storm events (Preston et al., 2003). Because of this, the lack of irrigation, especially in winter and early spring, is the limiting factor for grapevine cultivation in this region (Pszczólkowski et al., 2010). The amount of rainfall depends on the summer daytime temperature and, to a lesser degree, by the El Niño Southern Oscillation (ENSO) (Preston, 2000). During strong ENSO events, drought commonly occurs on the Andean Altiplano in the austral summer, whereas during anti-El Niño or La Niña phases, rainfall increases (Thompson et al., 1984). However, because of the high degree of variability of rainfalls, wetter than average months occur during dry ENSO periods (Preston, 2000; Preston et al., 2003). In the case of the Central Valley of Tarija, generally, the La Niña seasons are wetter, while the El Niño seasons are drier, which is the opposite of what occurs in the western coast of South America (Pszczólkowski et al., 2010). The vineyards can be affected by flooding when the summer rains are intense, which can cause soil erosion (Pszczólkowski et al., 2010). In addition, in the Central Valley of Tarija, thunder storms occur which is often accompanied by hail (Zamuriano et al., 2019). The use of anti-hail nets is an

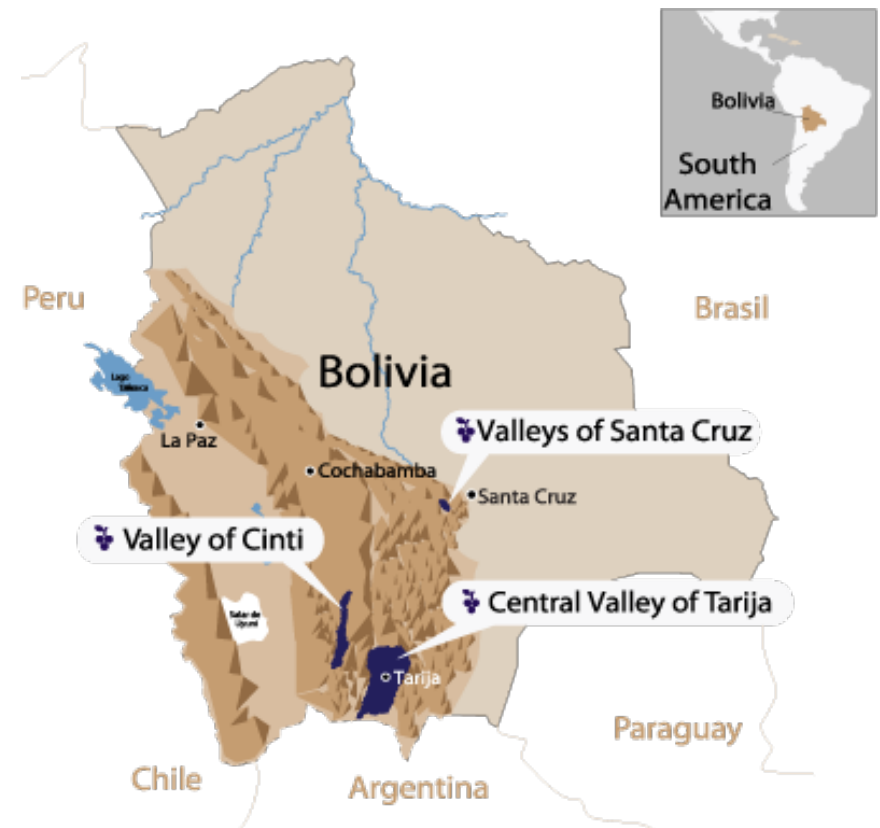

FIGURE 1

Wine Regions of Bolivia (Figure obtained by the report published by Wines of Bolivia, 2020). 
important current viticultural strategy to solve this problem (López Ávila, 2008). However, in most of the Bolivian viticultural valleys, endemic trees are planted within the vineyard. The foliage of the trees protect the vineyards from hail (Oliva Oller, 2021).

In Tarija, the frost-free period accounts seven months from October to April, whereas in Santa Cruz de La Sierra, it has a duration of eight months from October until May (Pszczólkowski et al., 2010; Aguilar and Pszczólkowski, 2012). In Tarija, the frosts are convective but in Santa Cruz de La Sierra the frost could be radiative or convective (Pszczólkowski et al., 2010; Aguilar \& Pszczólkowski, 2012). Hailstorms are frequent in the Andes and hail is typically formed in convective storms both locally and in the Amazon basin, where there is sufficient water vapour and favourable energy conditions (Andrade, 2017). The complex interaction between lakes, surface heating and orography favours deep convection and hailstorm formation (Zamuriano et al., 2019). In Tarija, frost, hailstorms and floods are responsible for grape production losses of between 25 to 50 $\%$ per season, a situation which is less critical in the valleys of the department of Santa Cruz since where there is less risk of hailstorms and floods (Pszczólkowski et al., 2010). To curb hailstorms, farmers install anti-hail nets, preferably cover nets, since it allows the mechanization of certain practices, such as pre-pruning, phytosanitary applications and harvesting (López Ávila, 2008) which allows sufficient irradiation and ventilation of grapevines, and also reducing the incidence of cryptogamic diseases by $65 \%$ per hectare (López Ávila, 2008).

An advantage to mitigate global warming is that altitude causes a decrease in temperature, creating a more temperate climate, due to adiabatic cooling of the air at a rate of $0.6{ }^{\circ} \mathrm{C}$ every $100 \mathrm{~m}$ (Pszczólkowski et al., 2010; Gutiérrez-Gamboa et al., 2020). This altitude-related cooling is attenuated by the effects of strong solar radiation, low cloudiness and low precipitation that characterize winter in Tarija (Pszczólkowski et al., 2010). But in part, these unfavourable conditions for the accumulation of winter temperatures, are compensated by the wind coming from the inter-Andean valleys, located at the south-east of the Central Valley of Tarija (Pszczólkowski et al., 2010). In this valley, the average accumulation of chilling hours over a series of 45 years was 337 hours (Pszczólkowski et al., 2010). However, the average accumulated of the last ten years is only 269 hours, showing a clear decreasing trend as is reported by Anzanello et al. (2018), Fraga et al. (2019) and Santos et al. (2019).

Previous studies indicate that the chilling exposure necessary for normal bud growing ranges between 50 and 400 hours at temperatures lower than $7{ }^{\circ} \mathrm{C}$ (Dokoozlian, 1999; Dokoozlian et al., 1995). As is shown in Fig. 2, in warm regions where winter temperatures rarely reach below $7{ }^{\circ} \mathrm{C}$, insufficient chilling can result in delayed and desynchronized budburst (Londo \& Johnson, 2014). By consequence, shoot number, bunch number, and fruit ripening rates are all negatively affected, which result in a decrease in vineyard productivity (Dokoozlian et al., 1995; Dokoozlian, 1999; Londo \& Johnson, 2014). In the viticultural regions where achieving chilling is problematic, the use of hydrogen cyanamide has proven to improve budburst (Dokoozlian et al., 1995). However, this chemical regulator also advances budburst, increasing the risk of spring frost damage, and therefore, it is not used in Bolivian vineyard management (Pszczólkowski et al., 2010; Gutiérrez-Gamboa et al., 2020).

Pruning practices such as cane pruning, late winter pruning, double-pruning or pruning the spurs leaving one bud, may partially solve heterogeneous budburst by insufficient chilling, without advancing the date of budburst (Pszcolkowski et al., 1983; Pszczólkowski et al., 2010). Pruning to one bud favours the burst of the base bud providing acrotony control (Pszczólkowski \& Villena, 2009). Hence, the use of low chill cultivars would likely reduce the need for budburst induction via physical or chemical intervention techniques (Londo \& Johnson, 2014). As stated by Pszczólkowski et al. (2010) interspecific hybrids such as Favorita Diaz and Monte Rico (Concord 'Vitis labrusca) are the most adapted cultivars under the subtropical conditions. Cultivars such as Cardinal, Italia and Red Globe for table
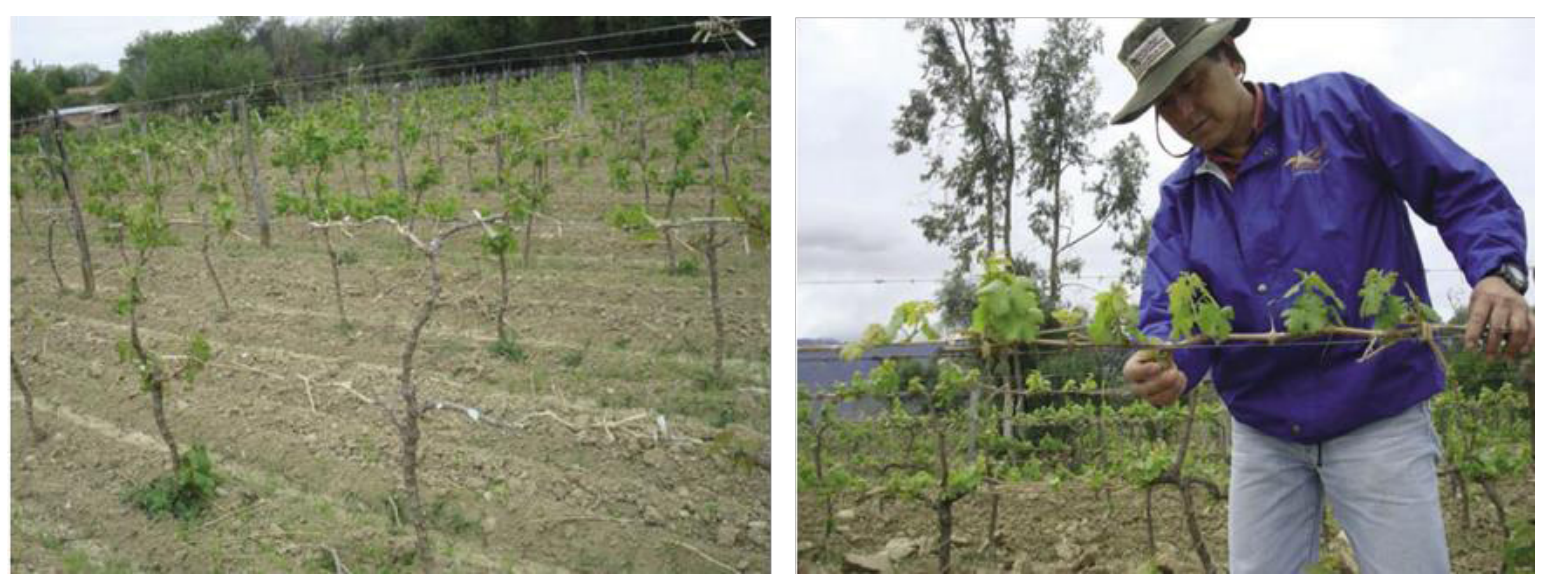

FIGURE 2

Acrotony and heterogeneous bud burst due to the lack of winter cold in Santa Ana la Nueva vineyard in Central Tarija Valley (left). Homogeneous budburst as consequence of pruning practices on Carmenère in Calamuchita vineyard in Central Tarija Valley (right). (Figure obtained by the manuscript published by Pszczólkowski et al., 2010). 
grape production are reasonably adapted. Certain Criolla cultivars used for table grape production, wine and spirit production such as Vicchoqueña, Negra Criolla, Blanca Redonda, Rosada Criolla, Moscatel San Juanina, Mollar, as well as Alphonse Lavallée, Ribier, Cereza, Pedro Giménez and Torontel are also reasonably adapted. Vinifera cultivars, i.e. Chardonnay, Cabernet Franc, Cabernet Sauvignon, Carmenère, Merlot, Petit Verdot, Pinot Blanc, Pinot Gris, Meunier, Pinot Noir, Riesling, Sauvignon blanc, Chenin blanc, Colombard, Malbec, Sauvignon vert and Syrah show a deficient adaptation to subtropical conditions due to their need for high winter cold. However, Tannat grapes appears to be well suited to Bolivian viticulture conditions. Some Mediterranean cultivars such as Bonarda, Carignan, Grenache, Nebbiolo, Sangiovese, Tempranillo and Ugni Blanc, present a better adaptation to the subtropical conditions of Central Valley of Tarija than the above mentioned Vinifera cultivars. Therefore, understanding variation in chilling requirements will prepare grapevine breeders and producers for the projected changes in global climate (Londo \& Johnson, 2014).

The spectrum of solar UV radiation reaching the surface of the Earth ranges between $290 \mathrm{~nm}$ and $400 \mathrm{~nm}$, which are equivalent to quantum energies between $4.278 \mathrm{eV}$ and 3.102 eV (Piazena \& Häder, 2009). Sun elevation above the zenith changes during the day and seasons, thereby UV-B levels are higher at midday and summertime in the tropics, than in other zones of the Hemisphere (Piazena, 1996). The impact of altitude is related to the atmospheric column mass that solar rays must traverse, and at high altitudes there is less air masses and hence greater solar UV-B levels (Piazena, 1996). In subtropical Andean regions, during the summer months and especially during the wet season, the cloudiness is enhanced, leading to increased incoming long-wave radiation (Francou et al., 2003). In general, UV irradiance increases with altitude because of the decreasing quantity in absorbing and scattering material above the observer (Pfeifer et al., 2006). At solar elevations between $20^{\circ}$ and $90^{\circ}$ the increase of the global irradiance is about 8 to $10 \%$ every $1000 \mathrm{~m}$ for UV-B and changed from 15 to $7 \%$ every 1000 $\mathrm{m}$ for UV-A (Piazena, 1996). Moreover, albedo effect further enhances UV irradiance with altitude since albedo increases with altitude because of increased probability of snow and the change from vegetation to rocks (Pfeifer et al., 2006). The column ozone is thinner over the tropics compared to northern mid-latitude, and UV increases in relation to the elevation (Fig. 3), clear skies, and low aerosols (Blumthaler et al., 1994). In the high-elevation zones of Bolivia, extreme UV-B (280-315 nm) irradiance equivalent to a UV index of 43.3 was recorded, which is the highest ground value ever reported (Cabrol et al., 2014). By consequence, the tropical Andes zones represent a particularly valuable study area for quantifying the effects of biologically damaging radiation (UV-A, UV-B) on crop productivity and quality (Piazena, 1996). The total UV-B irradiance measured at Central Valley of Tarija, is up to $6.2 \mathrm{~W} \mathrm{~m}^{2}$ in summer and $2.1 \mathrm{~W} \mathrm{~m}^{-2}$ in winter, corresponding to a UV-B index of 14 in summer and 6 in winter (Taquichiri et al., 2014).

\section{UV RADIATION EFFECTS ON THE SYNTHESIS OF PHENOLIC COMPOUNDS IN GRAPES}

The common protective response of grapevines against UV-B radiation is the biosynthesis of UV-absorbing compounds that are accumulated in epidermal vacuoles (Kolb et al., 2001; Berli et al., 2011). Abscisic acid (ABA) is involved in the response of grape leaf tissues to UV-B radiation by enhancing the synthesis of UV-absorbing compounds, antioxidant enzymes and membrane sterols (Kolb et al., 2001; Berli et al., 2009). Indeed, previous incidence of high UV-B in grapevines prevented deleterious effects of water deficit on berry weight reduction and decrease of sugar accumulation (Alonso et al., 2016). UV-B modulates the accumulation of sugars and upregulates anthocyanin biosynthesis in grapevines and compensated the deleterious

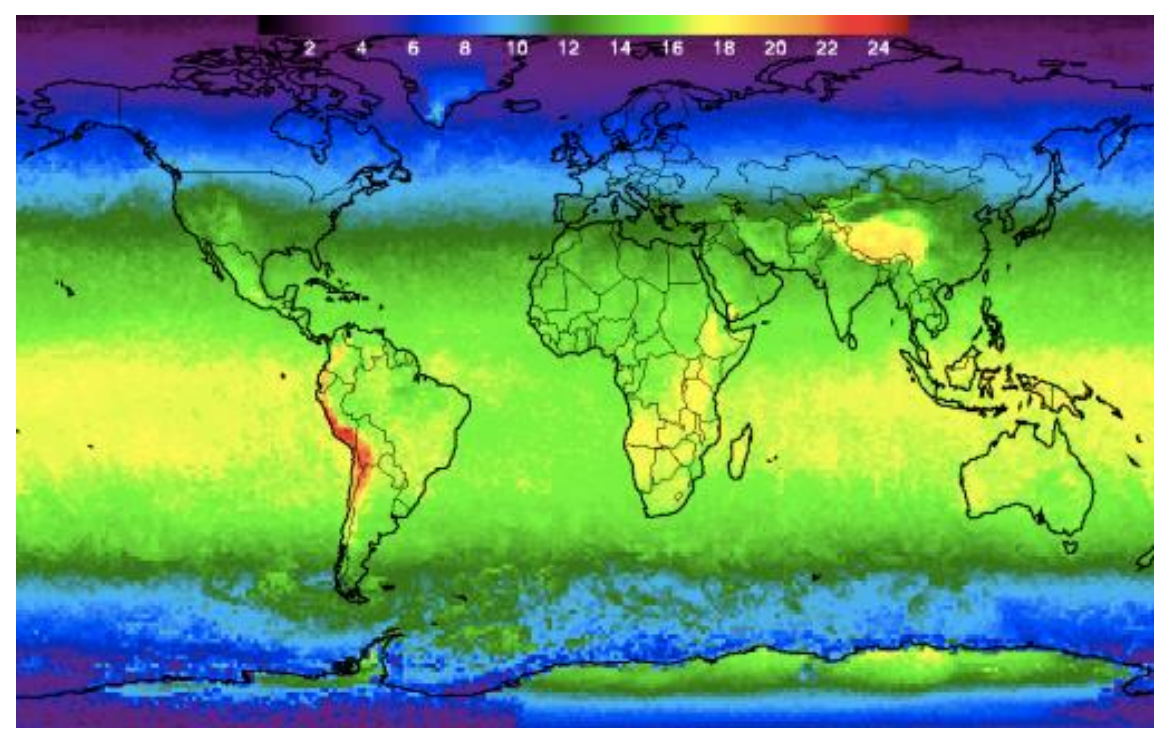

FIGURE 3

Map of peak of UV Index (UVI), using a modified colour scale to highlight the absolute peaks (Figure obtained by the report published by Liley and Mckenzie, 2006). 
effect of elevated atmospheric carbon dioxide $\left(\mathrm{CO}_{2}\right)$ and increased temperature on berry anthocyanin concentration (Martínez-Lüscher et al., 2016). UV-B radiation slowed berry development and upregulated flavonol and anthocyanin biosynthesis (Martínez-Lüscher et al., 2016). Moreover, viticultural practices that result in the exposure of grape bunches to UV-B radiation, may alleviate the effect of elevated atmospheric $\mathrm{CO}_{2}$ and increased temperature on grape anthocyanin concentration, which occur in Bolivia vineyards. Supporting this, a preliminary study showed that photosystem II (PSII) in chloroplasts is protected against UV-B damage by epidermal screening (Kolb et al., 2001). These authors suggested that the protection of UV-B inactivation of PSII is because preceding damage is repaired, while those factors determining UV-B inhibition of $\mathrm{CO}_{2}$ assimilation recover more slowly.

UV-radiation activates specific signalling pathways in grape skins from grapevines established at mid-altitudes and by consequence, the accumulation and synthesis of secondary metabolites that potentially confer cross-tolerance, are specifically triggered (Carbonell-Bejerano et al., 2014). Two key biosynthetic genes (UFGT and FLS1) concomitantly are up-regulated by UV-B radiation, leading to an increase in anthocyanin and flavonol concentration in skins (Gregan et al., 2012; Martínez-Lüscher et al., 2014). The changes in flavonol and anthocyanin concentration are explained to a large extend by transcript levels of $F 3^{\prime} H, F 3^{\prime} 5^{\prime} H$ and $O M T 2$, affected by UV-B radiation (Martínez-Lüscher et al., 2014). Secondary metabolism related transcripts are induced by UV radiation including $V v F L S 1, V v G T 5$ and $V v G T 6$ flavonol biosynthetic genes, which result in an increase in flavonols accumulation in skin grapes (Carbonell-Bejerano et al., 2014). The transcriptional activation of structural ( $V v A N R$, $V v L A R 1$ and $V v L A R 2)$ and regulatory (VvMYB5a, VvMYB5b and $V v M Y B P A 1)$ genes involved on flavanol biosynthesis in grapes depend on developmental stage in which grapes are affected by UV-radiation, since it enhanced gene expression and flavanol content only in unripen grapes (3 weeks after flowering), compared to the mature grapes (11 weeks after flowering) (Zhang et al., 2013). UV-B radiation generates a phenolic-based resistance against Botrytis cinerea through the activation of the phenylpropanoid biosynthetic pathway (Demkura \& Ballaré 2012; Matus, 2016). Based on literature (Flamini et al., 2013; Gindro et al., 2017), it is known that grapevine diseases allow the induction of stilbene synthase (STS) in grapevine cells. Therefore, UV-light irradiation can stimulate STS transcript of unripe berries, harvested from Corvina grapevines (Versari et al., 2001).

Based on results obtained in vineyards cultivated in Bolivia (Table 1), it was reported that Syrah wines from Pampa Colorada (1.729 m. a. s. 1) and Santa Ana (1.800 m. a. s. 1) sites had higher alcohol content, colour intensity (CI), total polyphenol index (IPT) and anthocyanins content than the wines from Pampa la Villa (1.719 m. a. s. 1) and La Compañía (1.721 m. a .s. 1) (Ceppi de Lecco \& Castillo, 2008). Cabernet Sauvignon wines obtained from these sites were not significantly different in phenolic composition but wines from Pampa Colorada and Santa Ana showed higher total anthocyanin content than the wines from Pampa la Villa and La Compañía (Ceppi de Lecco \& Castillo 2008).
Recently, Arteaga et al. (2020) reported that total tannin content in commercial wines from Central Valley of Tarija ranged from 0.21 to $4.97 \mathrm{~g} / \mathrm{L}$. Regarding other compounds, it was reported that some South American wines from grapevines growing at high altitude (higher than $1.500 \mathrm{~m}$. a. s. 1 as in Tarija and Santa Cruz in Bolivia, and Salta in Argentina) had higher total antioxidant capacity (TAC) and phenolic content, including resveratrol than wines from the low-altitude vineyards (Osorio-Macías et al., 2018).

Taquichiri et al. (2014) reported that trans-resveratrol content in grapes from Central Valley of Tarija was significantly higher than the grapes collected in the Loayza province and in other viticultural countries (Taquichiri et al., 2014). These authors related the differences on solar UV-B radiation levels with the oxidative processes that affect the synthesis of trans-resveratrol in grapes. Similar results for trans-resveratrol were found in wines from Bolivia (7.7 $\mathrm{mg} / \mathrm{L}$ ), compared to those from other countries (from 1.0 to $3.2 \mathrm{mg} / \mathrm{L}$ ) by Bustos et al. (2012). In addition, Syrah grapes had the highest concentration of trans-resveratrol and therefore can be assume that this cultivar is more affected by UV radiation exposure, compared to most of Vitis vinifera grapevine cultivars cultivated in Bolivia (Ceppi de Lecco \& Castillo 2008; Taquichiri et al., 2014). Moreover, it is possible that high UV-B radiation could have a negative effect on the quality of grapes (Fig. 4), causing sunburn damage to grapes, thereby affecting the tonality of the produced wines (Ayarde Mogro et al., 2012). Under these conditions, the attenuation of UV-B radiation using anti-hail mesh can be an alternative to reduce sunburn damage (Ayarde Mogro et al., 2012).

The high concentration of resveratrol and antioxidants found in Bolivian wines can mainly be attributed to the high altitudes (Andrade et al., 1998). However, in some cultivars, delaying ripening can increase the stilbene content of grapes but insufficient extraction of these compounds during winemaking can limit their concentration in wines (Favre et al., 2020). In addition, other studies have found direct associations between the UV-B radiation and the increment of the content of flavanols, flavonols and stilbenes and thereby the antioxidant activity in grapes and wines (Taquichiri et al., 2014; Alonso et al., 2016; Del-Castillo-Alonso et al., 2020). Plant defence mechanisms towards UV-B signal, promote the production of antioxidant secondary metabolites, instead of primary metabolites (Takshak \& Agrawal, 2019; Liu et al., 2020). UV-B radiation decreased net photosynthesis and stomatal conductance, mainly through the limitation in gas exchange, reducing leaf area, net carbon fixation and plant growth (Berli et al., 2013). Morphologically, UV-B radiation induces an increase on leaf thickness, including the quantity of photoprotective pigments and proline, thereby increasing the antioxidant capacity of leaves (Berli et al., 2013). These authors suggested that UV-B effects on grapevine metabolic responses depend on tissues developmental stage and interplay with total radiation and air temperatures (Berli et al., 2013). In this way, high fluence rate UV-B seemed to had regulatory effects on the defence or general multiplestress responses pathways but low fluence rate UV-B promoted the expression of genes that could be involved in UV-B protection or the amelioration of the UV-B-induced damage. (Pontin et al., 2010) These results can be linked to 

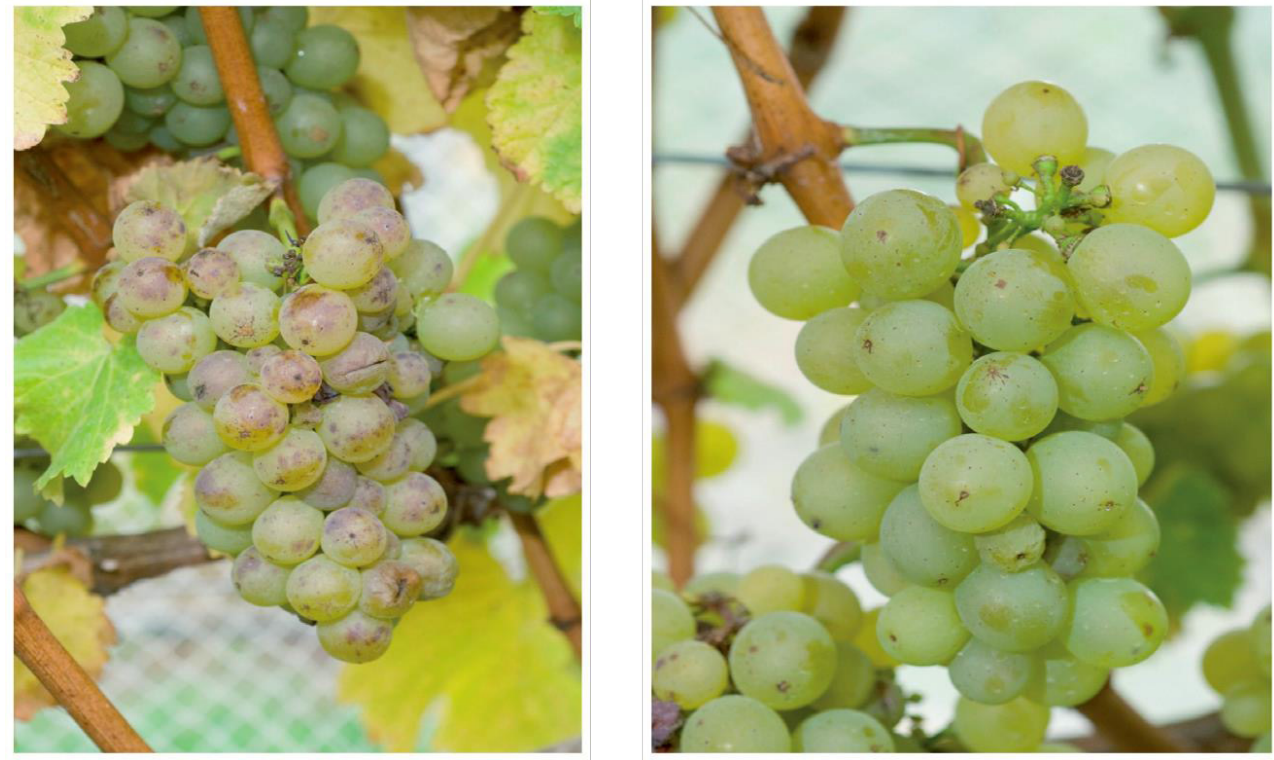

FIGURE 4

UV-B damage in Muscat of Alexandria bunches. On the left there is a bunch without UV-B attenuation and on the right, the bunch present $60 \%$ UV-B attenuation using anti-hail meshes (Figure obtained by the report published by Ayarde Mogro et al., 2012).

the effect of global warming on viticulture since it has been showed that UV-B alleviated the senescence-related lipid peroxidation induced by elevated $\mathrm{CO}_{2}$-temperature but not by deficit irrigation (Martínez-Lüscher et al., 2015a,b).

\section{UV RADIATION EFFECTS ON THE SYNTHESIS OF OTHER COMPOUNDS IN GRAPES}

Volatile organic compounds (VOCs) are produced by plants as signalling molecules that interact with the physical and biotic environment (Delory et al., 2016, Ninkovic et al., 2020). VOCs protect plant tissues against abiotic stressful factors through the decrease in the oxidative damage by the synthesis of antioxidant compounds and play a key role on grape varietal aroma of wines (González-Barreiro et al., 2015; Faiola \& Taipale, 2020). To our knowledge, there is no published reports that studies the effects of UV-B radiation on the synthesis of secondary metabolites other than polyphenols in grapes produced from Bolivian vineyards. However, some national oenologists emphasize the fact that cultivating vines in Bolivia, especially in the Central Valley of Tarija, produce wines with high content of terpenes and intense aromatic wines and distillates due to the exposure of the grapevines to varying UV-B radiation. This opinion contrast to the report by Lafontaine et al. (2005) who found that UV-B radiation decreased the content of volatile compounds, i.e. mostly terpenes and norisoprenoids. Radiation intensities depend on the row direction and altitude of the vineyard. For example, $\mathrm{N}-\mathrm{S}$ orientated rows can receive a maximum photosynthetic active radiation twice a day with approximately $60 \mu \mathrm{mol} \mathrm{m} \mathrm{m}^{-2}$ $\mathrm{s}^{-1}$ inside the canopy and close to $1,000 \mu \mathrm{mol} / \mathrm{m} / \mathrm{s}$ radiation outside the canopy during late morning for southern hemisphere. For example, NE-SW orientated rows can receive up to $80 \mu \mathrm{mol} \mathrm{m} \mathrm{m}^{-2} \mathrm{~s}^{-1}$ radiation inside the canopy and close to $1300 \mu \mathrm{mol} / \mathrm{m} / \mathrm{s}$ radiation outside the canopy during mid-afternoon (Hunter et al., 2016).
Regarding work by other authors, high intensity UV-B irradiation $\left(0.33 \mathrm{~W} \mathrm{~m}^{2}\right.$ during the last $4 \mathrm{~h}$ of a $16 \mathrm{~h}$ day photoperiod) to grapevine leaves grown in vitro, allowed the synthesis of $\alpha$-pinene, 3 -carene, terpinolene and nerolidol that are considered a strong antioxidant. (Gil et al., 2013) In addition, UV-B irradiation to Malbec grapes increased the content of terpenes at preharvest stages ( 90 days after flowering) as well as the content of hexanal and 5-hepten2-one, whereas terpenes content decreased towards harvest (Gil et al., 2013) Sunlight and UV exposure of grape bunches affected terpene, alcohols, $\mathrm{C}_{13}$-norisprenoids and other volatile composition of the wine differently (Song et al., 2015). These parameters enhanced the nerol, geraniol and citronellol content of wine but not linalool. Neither basal leaf removal nor UV transmission treatments, that allowed to increase bunch exposure to radiation, showed any effects on the content of $\beta$-damascenone in Pinot Noir wines (Song et al., 2015). Terpene synthase (TPS) genes expression occurs during the later stages of berry development and some researchers suggest that low UV-B irradiance trigger acclimation processes via induction of TPS, resulting in terpene biosynthesis. (Lücker et al., 2004; Gil et al., 2012; Alonso et al., 2016). In contrast, $\beta$-D-glucosyltransferases promote the conversion of free terpenes to glycosidic form, allowing the glycosylation of monoterpenes progresses towards harvest (Miao et al., 2020) As a result, the effects of UV on free terpenes in grapes at harvest may be not significant as stated previously (Gil et al., 2012; Liu et al., 2015; Miao et al., 2020). Linalool is one of the most sensitive monoterpene compound to sunlight exposure, whose biosynthesis was inhibited by sunlight exclusion where after it was enhanced by the re-exposure to radiation (Zhang et al., 2017). Glycosylated geraniol and ocimene presented suppressive and stimulative responses to sunlight exclusion, respectively (Zhang et al., 2017). VvPNLinNerl, 
$V v C S b O c i, V v G T 7$ and $V v G T 14$ genes are mainly responsible for monoterpene accumulation and sensitivity to sunlight (Zhang et al., 2017). VvDXS2 and $V v D X R$ genes are related in certain degree to the differential accumulation of total terpenes under different sunlight treatments performed by sunlight exclusion by bagging clusters in opaque boxes (Zhang et al., 2017).

Nitrogen compounds such as amino acids are molecules that play a key position in grapevine metabolism and play a major role in the biological functions of fermentative microbes and as flavour components of wines (Gregan et al., 2017). Proteins, proline and carbohydrates are important osmoprotectants that are synthesized in plants in response to adverse environmental conditions (Ashraf, 2010; Dawood et al., 2014). These osmoprotectants protect the plants from abiotic stresses adjusting cellular osmosis, scavenging reactive oxygen species, protecting cellular membranes, and stabilizing proteins/enzymes and enzyme activities (Gill \& Tuteja, 2010). In this way, Berli et al. (2013) showed that proline content increased in grapevine leaves after exposition to specifically UV-B radiation under field conditions. Zhu et al. (2017) reported that grapevines exposed to UV-B radiation under glasshouse conditions, decreased the content of total amino acids and some individual amino acids in grapes between 41 to $93 \%$. Total free amino acid content of Tempranillo grapes harvested from fruit-bearing cuttings, exposed to two UV-B treatments (5.98 and $9.66 \mathrm{~kJ} \mathrm{~m}^{-2} \mathrm{~d}^{-1}$ ) was not affected (Martínez-Lüscher et al., 2014). In terms of individual amino acids, UV-B radiation increased the content of gamma-aminobutyric acid (GABA), but decreased threonine, isoleucine, methionine, serine and glycine content, revealing a potential effect of UV-B on the GABA-mediated signalling and amino acid metabolism (Martínez-Lüscher et al., 2014).

\section{CONCLUSION}

Bolivian vineyards are mostly located at 1,660 to 2,360 metres above sea level which is higher than several of the cultivated vineyards worldwide. Bolivia is characterized by a subtropical altitude viticulture, and according to Köppen classification, the climate corresponds to a cool semi-arid zone, with a large mesoclimatic variability. Under these edaphoclimatic conditions, UV-B radiation increases at 8 to $10 \%$ every $1000 \mathrm{~m}$ of altitude. Moreover, the altitude causes a decrease in temperature, creating a more temperate climate, due to adiabatic cooling of the air at a rate of $0.6{ }^{\circ} \mathrm{C}$ every $100 \mathrm{~m}$ of altitude and could be an effective strategy to face global warming in viticulture. The above-mentioned climatic features open an opportunity to Bolivia to practice viticulture. Grapes and wines obtained from high-altitude Bolivian vineyards have high levels of trans-resveratrol and antioxidants, mainly attributed to the effects of UV-B radiation on activation of plant defence mechanisms. The study of secondary metabolites related to wine flavour deserve investigation but is currently limited due to the few public policies developed in relation to wine sciences. Despite the efforts made by the national industry, some trials have not been conducted under controlled conditions and it is possible that research performed under field conditions are not able to generate conclusive information in this regard.
Based on this, Bolivian viticulture represents a valuable study region for quantifying the effects of biologically damaging radiation on grapevine productivity, and grape and wine quality.

\section{LITERATURE CITED}

Aguilar, R. \& Pszczólkowski, P., 2012. Development of Bolivian viticulture in temperate ('mesothermic') valleys of Santa Cruz de La Sierra. Progr. Agric. Vitic. 129, 7-19.

Alonso, R., Berli, F.J., Fontana, A., Piccoli, P. \& Bottini, R., 2016. Malbec grape (Vitis vinifera $\mathrm{L}$.) responses to the environment. Berry phenolics as influenced by solar UV-B, water deficit and sprayed abscisic acid. Plant Physiol. Biochem. 109, 84-90.

Alonso, R., Berli, F.J., Piccoli, P. \& Bottini, R., 2016. Ultraviolet-B radiation, water deficit and abscisic acid. a review of independent and interactive effects on grapevines. Theor. Exp. Plant Physiol. 28(1), 11-22.

Andrade, M.F., 2017. Climate and extreme events from the Central Altiplano of Peru and Bolivia. Imprenta A. G. Carrasco.

Andrade, P., Seabra, R., Ferreira, M., Ferreres, F. \& García-Viguera, C., 1998. Analysis of non-coloured phenolics in port wines by capillary zone electrophoresis. Influence of grape variety and ageing. Z. Lebensm. Unters. Forsch. 206(3), 161-164

Anzanello, R., Fialho, F.B., dos Santos, H.P., Anzanello, R., Fialho, F.B. \& dos Santos, H. P., 2018. Chilling requirements and dormancy evolution in grapevine buds. Ciênc. e Agrotecnologia 42(4), 364-371.

Apaza-Gutiérrez, V., Romero-Saravia, A., Guillén-Portal, F.R. \& Baltensperger, D. D., 2002. Response of grain amaranth production to density and fertilization in Tarija, Bolivia. In: Janick, J \& Whipkey, A (eds.), Trends in new crops and new uses. ASHS Press. pp. 107-109.

Arteaga, M.C., Callisaya, J.C., Gutiérrez, P., Taquichiri, M. \& Paco, J., 2020. Análisis comparativo del contenido de taninos en vinos comerciales de Tarija, Bolivia. Ciencia Sur 2(2), 67-74.

Ashraf, M., 2010. Inducing drought tolerance in plants. Recent advances. Biotechnol. Adv. 28(1), 169-183.

Ayarde Mogro, R., Gutiérrez Barea, P.M., Taquichiri, M., Velasquez, A., Villa, M., Acosta, N., Peñarrieta, J.M., Cortez, P., Quisberth, B. \& Alvarado, A.J., 2012. Evolución temporal de antioxidantes totales en variedades de Vitis vinifera del valle central de Tarija. Revista Ventana Cientifica 1(4), 19-26.

Bastian, E. \& Gräfe, W., 1989. Afforestation with "multipurpose trees" in "media lunas", a case study from the Tarija basin, Bolivia. Agrofor. Syst. 9(2), 93-126.

Berli, F., D’Angelo, J., Cavagnaro, B., Bottini, R., Wuilloud, R. \& Silva, M.F., 2008. Phenolic composition in grape (Vitis vinifera L. cv. Malbec) ripened with different solar UV-B radiation levels by capillary zone electrophoresis. J. Agric. Food Chem. 56(9), 2892-2898.

Berli, F., Fanzone, M., Piccoli, P. \& Bottini, R., 2011. Solar UV-B and $\mathrm{ABA}$ are involved in phenol metabolism of vitis vinifera L. Increasing biosynthesis of berry skin polyphenols. J. Agric. Food Chem. 59(9), 48744884 .

Berli, F.J., Alonso, R., Bressan-Smith, R. \& Bottini, R., 2013. UV-B impairs growth and gas exchange in grapevines grown in high altitude. Physiol. Plant. 149, 127-140

Berli, F., Moreno, D., Piccoli, P., Hespanhol-Viana, L., Silva, M.F., Bressan-Smith, R., Cavagnaro, J.B. \& Bottini, R., 2009. Abscisic acid is involved in the response of grape (Vitis vinifera L.) cv. Malbec leaf tissues to ultraviolet-B radiation by enhancing ultraviolet-absorbing compounds, antioxidant enzymes and membrane sterols. Plant Cell Environ. 33(1), 1-10. 
Blancquaert, E.H., Oberholster, A., Ricardo-da-Silva, J.M. \& Deloire, A.J., 2019. Grape flavonoid evolution and composition under altered light and temperature conditions in Cabernet Sauvignon (Vitis vinifera L.). Fron. Plant Sci. 10, 1062.

Blumthaler, M., Webb, A.R., Seckmeyer, G., Bais, A.F., Huber, M. \& Mayer, B., 1994. Simultaneous spectroradiometry. A study of solar UV irradiance at two altitudes. Geophys. Res. Lett. 21(25), 2805-2808.

Buitrago Soliz, A., 2014. La vitivinicultura emergente en Bolivia y las oportunidades para el Singani. RIVAR. 1(2), 87-101.

Bustos, A.-S., Calisaya, J.C., Paredes, C., Duran, G., Taquichiri, M., Alvarado, J.A. \& Peñarrieta, J.M., 2012. Cuantificación de resveratrol en vinos mediante HPLC. Rev. Bol. Quim. 29(2), 164-169.

Cabrol, N.A., Feister, U., Häder, D.-P., Piazena, H., Grin, E.A. \& Klein, A., 2014. Record solar UV irradiance in the tropical Andes. Front. Environ. Sci. 2, 19.

Carbonell-Bejerano, P., Diago, M.P., Martínez-Abaigar, J., MartínezZapater, J.M., Tardáguila, J. \& Núñez-Olivera, E., 2014. Solar ultraviolet radiation is necessary to enhance grapevine fruit ripening transcriptional and phenolic responses. BMC Plant Biol. 14(1), 183.

Casanova-Gascón, J., Martín-Ramos, P. \& Badía-Villas, D., 2018. Nutrients assimilation and chlorophyll contents for different grapevine varieties in calcareous soils in the Somontano DO (Spain). Beverages. 4(4), 90.

Ceppi de Lecco, C. \& Castillo, I. P., 2008. Caracterización de cepas y vinos Syrah y Cabernet Sauvignon en cuatro zonas del Valle Central de Tarija. Rev. Bol. Quim. 25(1), 62-69.

Compés, R. \& Sotés, V., 2018. El sector vitivinícola frente al desafío del cambio climático.

Coppus, R., 2002. Landscape sensitivity to erosion in three semi-arid central Andean Geo-Ecosystems. Institute for Biodiversity and Ecosystem Dynamics (IBED).

Dawood, M.G., Taie, H.A.A., Nassar, R.M.A., Abdelhamid, M.T. \& Schmidhalter, U., 2014. The changes induced in the physiological, biochemical and anatomical characteristics of Vicia faba by the exogenous application of proline under seawater stress. S. Afr. J. Bot. 93, 54-63.

Del-Castillo-Alonso, M.Á., Monforte, L., Tomás-Las-Heras, R., NúñezOlivera, E. \& Martínez-Abaigar, J., 2020. A supplement of ultraviolet-B radiation under field conditions increases phenolic and volatile compounds of Tempranillo grape skins and the resulting wines. Eur. J. Agron. 121, 126150 .

Delory, B.M., Delaplace, P., Fauconnier, M.L. \& du Jardin, P., 2016. Rootemitted volatile organic compounds. Can they mediate belowground plantplant interactions? Plant and Soil. 402(1-2) 1-26.

Demkura, P.V. \& Ballaré, C.L., 2012. UVR8 mediates UV-B-induced arabidopsis defense responses against botrytis cinerea by controlling sinapate accumulation. Mol. Plant. 5(3), 642-652.

Dokoozlian, N.K., 1999. Chilling temperature and duration interact on the budbreak of 'Perlette' grapevine cuttings. HortScience. 34(6), 1-3.

Dokoozlian, N.K., Williams, L.E. \& Neja, R.A., 1995. Chilling exposure and hydrogen cyanamide interact in breaking dormancy of grape buds. HortScience. 30(6), 1244-1247.

Faiola, C. \& Taipale, D., 2020. Impact of insect herbivory on plant stress volatile emissions from trees. A synthesis of quantitative measurements and recommendations for future research. Atmos. Environ. X 5, 100060.

Favre, G., Piccardo, D., Gómez-Alonso, S., Pérez-Navarro, J., GarcíaRomero, E., Mena-Morales, A. \& González-Neves, G., 2020. Stilbenes in Tannat, Marselan and Syrah grapes and wines from Uruguay. Oeno One 54, 27-36.
Flamini, R., Mattivi, F., De Rosso, M., Arapitsas, P. \& Bavaresco, L., 2013. Advanced knowledge of three important classes of grape phenolics. Anthocyanins, stilbenes and flavonols. Int. Mol. J Sci. 14(10), 19651-19669.

Fraga, H., Pinto, J.G. \& Santos, J.A., 2019. Climate change projections for chilling and heat forcing conditions in European vineyards and olive orchards. a multi-model assessment. Clim. Change 152(1), 179-193.

Francou, B., Vuille, M., Wagnon, P., Mendoza, J. \& Sicart, J. E., 2003. Tropical climate change recorded by a glacier in the central Andes during the last decades of the twentieth century. Chacaltaya, Bolivia, $16^{\circ} \mathrm{S}$. J. Geophys. Res. Atmos. 108(5), 4154

Gade, W.D., 2005. Vitivinicultura andina. difusión, medio ambiente y adaptación cultural. Treb. Soc. Catalana de Geogr. 58, 69-87.

Gill, S.S. \& Tuteja, N., 2010. Reactive oxygen species and antioxidant machinery in abiotic stress tolerance in crop plants. Plant Physiol. Biochem. 48(12), 909-930.

Gil, M., Pontin, M., Berli, F., Bottini, R. \& Piccoli, P., 2012. Metabolism of terpenes in the response of grape (Vitis vinifera $\mathrm{L}$.) leaf tissues to UV-B radiation. Phytochemistry. 77, 89-98.

Gil, M., Bottini, R., Berli, F., Pontin, M., Silva, M.F. \& Piccoli, P., 2013. Volatile organic compounds characterized from grapevine (Vitis vinifera L. cv. Malbec) berries increase at pre-harvest and in response to UV-B radiation. Phytochemistry. 96, 148-157.

Gindro, K., Schnee, S., Righi, D., Marcourt, L., Nejad Ebrahimi, S., Codina, J.M., Voinesco, F., Michellod, E., Wolfender, J.L. \& Queiroz, E.F., 2017. Generation of antifungal stilbenes using the enzymatic secretome of Botrytis cinerea. J. Nat. Prod. 80(4), 887-898.

González-Barreiro, C., Rial-Otero, R., Cancho-Grande, B. \& SimalGándara, J., 2015. Wine aroma compounds in grapes. A critical review. Crit Rev. Food Sci. Nutr. 55(2), 202-218.

Gregan, S.M., Wargent, J.J., Liu, L., Shinkle, J., Hofmann, R., Winefield, C., Trought, M. \& Jordan, B., 2012. Effects of solar ultraviolet radiation and canopy manipulation on the biochemical composition of Sauvignon Blanc grapes. Aust. J. Grape Wine Res. 18(2), 227-238.

Gregan, S. M., Winefield, C. \& Jordan, B., 2017. Amino acid metabolism and accumulation in 'Sauvignon Blanc' grapes - investigating berry composition in response to canopy manipulation. Acta Hortic. 1188, 9-14.

Grifoni, D., Carreras, G., Zipoli, G., Sabatini, F., Dalla Marta, A. \& Orlandini, S., 2008. Row orientation effect on UV-B, UV-A and PAR solar irradiation components in vineyards at Tuscany, Italy. Int. J. Biometeorol. 52(8), 755-763

Gutiérrez-Gamboa, G., Liu, S. \& Pszczólkowski, P., 2020. Resurgence of minority and autochthonous grapevine varieties in South America. a review of their oenological potential. J. Sci. f Food Agric. 100(2), 465-482.

Hunter, J., Volschenk, C. G., \& Zorer, R., 2016. Vineyard row orientation of Vitis vinifera L. cv. Shiraz/101-14 Mgt: Climatic profiles and vine physiological status. Agric. For. Meteorol. 228-229, 104-119.

Keller, M. \& Torres-Martinez, N., 2004. Does UV radiation affect winegrape composition? Acta Hortic. 640, 313-319.

Kolb, C.A., Käser, M.A., Kopecký, J., Zotz, G., Riederer, M. \& Pfündel, E.E., 2001. Effects of natural intensities of visible and ultraviolet radiation on epidermal ultraviolet screening and photosynthesis in grape leaves. Plant Physiol. 127(3), 863-875.

Lafontaine, M., Lopes, C., Schultz, H.R., Bálo, B. \& Váradi, G., 2005. Leaf and fruit responses of "Riesling" grapevines to UV-radiation in the field. Acta Hortic. 689, 125-132.

Liley, J. \& Mckenzie, R.L., 2006. Where on Earth has the highest UV? National Institute of Water and Atmospheric Research (NIWA), Lauder, Central Otago, New Zealand. 
Liu, D., Gao, Y., Li, X.-X., Li, Z. \& Pan, Q.-H., 2015. Attenuated UV radiation alters volatile profile in Cabernet Sauvignon grapes under field conditions. Molecules. 20(9), 16946-16969.

Liu, Y., Liu, J., Abozeid, A., Wu, K. X., Guo, X.R., Mu, L.Q. \& Tang, Z.H., 2020. UV-B radiation largely promoted the transformation of primary metabolites to phenols in Astragalus mongholicus seedlings. Biomolecules. 10(4), 504.

Londo, J.P. \& Johnson, L.M., 2014. Variation in the chilling requirement and budburst rate of wild Vitis species. Environ. Exp. Bot. 106, 138-147.

López Ávila, P., 2008. La malla antigranizo avanza a su fase II. Viñedos de Bolivia. 2, 3.

Lücker, J., Bowen, P. \& Bohlmann, J., 2004. Vitis vinifera terpenoid cyclases. Functional identification of two sesquiterpene synthase cDNAs encoding (+)-valencene synthase and (-)-germacrene D synthase and expression of mono- and sesquiterpene synthases in grapevine flowers and berries. Phytochemistry. 65(19), 2649-2659.

Martínez-Lüscher, J., Morales, F., Delrot, S., Sánchez-Díaz, M., Gomès, E., Aguirreolea, J. \& Pascual, I., 2015a. Characterization of the adaptive response of grapevine (cv. Tempranillo) to UV-B radiation under water deficit conditions. Plant Sci. 232, 13-22.

Martínez-Lüscher, J., Morales, F., Sánchez-Díaz, M., Delrot, S., Aguirreolea, J., Gomès, E. \& Pascual, I., 2015b. Climate change conditions (elevated $\mathrm{CO}_{2}$ and temperature) and UV-B radiation affect grapevine (Vitis vinifera $\mathrm{cv}$. Tempranillo) leaf carbon assimilation, altering fruit ripening rates. Plant Sci. 236, 168-176.

Martínez-Lüscher, J., Sánchez-Díaz, M., Delrot, S., Aguirreolea, J., Pascual, I. \& Gomès, E., 2014. Ultraviolet-B radiation and water deficit interact to alter flavonol and anthocyanin profiles in grapevine berries through transcriptomic regulation. Plant Cell Physiol. 55(11), 1925-1936.

Martínez-Lüscher, J., Sánchez-Díaz, M., Delrot, S., Aguirreolea, J., Pascual, I. \& Gomès, E., 2016. Ultraviolet-B alleviates the uncoupling effect of elevated $\mathrm{CO}_{2}$ and increased temperature on grape berry (Vitis vinifera $\mathrm{cv}$. Tempranillo) anthocyanin and sugar accumulation. Aust. J. Grape Wine Res. 22(1), 87-95.

Martínez-Lüscher, J., Torres, N., Hilbert, G., Richard, T., Sánchez-Díaz, M., Delrot, S., Aguirreolea, J., Pascual, I. \& Gomès, E., 2014. Ultraviolet-B radiation modifies the quantitative and qualitative profile of flavonoids and amino acids in grape berries. Phytochemistry. 102, 106-114.

Matus, J. T., 2016. Transcriptomic and metabolomic networks in the grape berry illustrate that it takes more than flavonoids to fight against ultraviolet radiation. Front. Plant Sci. 7, 1337

McKenzie, R.L., Aucamp, P.J., Bais, A.F., Björn, L.O. \& Ilyas, M. 2007. Changes in biologically-active ultraviolet radiation reaching the Earth's surface. Photochem. Photobiol. Sci. 6(3), 218-231.

Miao, W., Luo, J., Liu, J., Howell, K. \& Zhang, P., 2020. The influence of $\mathrm{UV}$ on the production of free terpenes in Vitis vinifera $\mathrm{cv}$. Shiraz. Agronomy. 10(9), 1431.

Ninkovic, V., Markovic, D. \& Rensing, M., 2020. Plant volatiles as cues and signals in plant communication. Plant Cell Environ. 44(4), 1030-1043.

Oliva Oller, P. R. (2021). Caracterización de los productores de vid en las principales zonas vitivinícolas de Bolivia. RIVAR. 8(23), 51-70.

Osorio-Macías, D., Vásquez, P., Carrasco, C., Bergenstahl, B. \& Penarrieta, M., 2018. Resveratrol, phenolic antioxidants, and saccharides in South American red wines. Int. J. Wine Res. 10, 1-11.

Pavlousek, P., 2013. Tolerance to lime - Induced chlorosis and drought in grapevine rootstocks. In: Vahdati, K \& Leslie, C (eds.), Abiotic stress - Plant responses and applications in agriculture. InTech. pp. 277-305.
Pezet, R., Gindro, K., Viret, O. \& Spring, J. L., 2004. Glycosylation and oxidative dimerization of resveratrol are respectively associated to sensitivity and resistance of grapevine cultivars to downy mildew. Physiol. Mol. Plant Path. 65(6), 297-303.

Pfeifer, M. T., Koepke, P. \& Reuder, J., 2006. Effects of altitude and aerosol on UV radiation. J. Geophys. Res. 111, D01203.

Piazena, H., 1996. The effect of altitude upon the solar UV-B and UV-A irradiance in the tropical Chilean andes. Solar Energy. 57(2), 133-140.

Piazena, H. \& Häder, D.-P., 2009. Solar UV-B and UV-A irradiance in arid high-mountain regions. Measurements on the island of Tenerife as compared to previous tropical Andes data. J. Geophys. Res. Biogeosci. 114, G04024.

Pontin, M.A., Piccoli, P.N., Francisco, R., Bottini, R., Martinez-Zapater, J.M. \& Lijavetzky, D., 2010. Transcriptome changes in grapevine (Vitis vinifera $\mathrm{L}$.) $\mathrm{cv}$. Malbec leaves induced by ultraviolet-B radiation. BMC Plant Biol. 10(1), 224.

Preston, D., 2000. The Southern Oscillation and rainfall in SW Tarija. https.//assets.publishing.service.gov.uk/

Preston, D. \& Clewer, L., 1993. Wine production in a marginal area. Tarija wine in the 1990s. J. Wine Res. 4(3), 227-232.

Preston, D., Fairbairn, J., Panlagua, N., Yevara, M., Beck, S. \& Maas, G., 2003. Grazing and environmental change on the Tarija Altiplano, Bolivia. Mt. Res. Dev. 23(2), 141-148.

Pszcolkowski, P., García, C. \& Varas, V., 1983. Effect of cane lenght, a second cane pruning and thiourea applications on bud break of grape vines. Cienc. Investig. Agrar. 10(2), 123-133.

Pszczólkowski, P., 2008. Evaluación de medio término. Progama de apoyo a la cadena productiva uvas, vinos y singanis.

Pszczólkowski, P., \& Villena, W., 2009. Acrotonía de la vid, factor a considerar en la viticultura subtropical de altura tarijeña. Viñedos de Bolivia. 4, 5-6.

Pszczólkowski, P., Villena, W. \& Carbonneau, A., 2010. La viticulture de la Bolivie, Centrée sur la Vallée Centrale de Tarija. Progr. Agric. Vitic. 127(1), 6-22.

Reyes, J., Del Campillo, M. \& Torrent, J., 2006. Soil properties influencing iron chlorosis in grapevines grown in the Montilla-Moriles area, southern Spain. Commun. Soil Sci. Plant Anal. 37(11-12), 1723-1729.

Santos, J.A., Costa, R. \& Fraga, H., 2019. New insights into thermal growing conditions of Portuguese grapevine varieties under changing climates. Theor. Appl. Climatol. 135(3-4), 1215-1226.

Song, J., Smart, R., Wang, H., Dambergs, B., Sparrow, A. \& Qian, M.C., 2015. Effect of grape bunch sunlight exposure and UV radiation on phenolics and volatile composition of Vitis vinifera L. cv. Pinot noir wine. Food Chem.173, 424-431.

Takshak, S. \& Agrawal, S.B., 2019. Defense potential of secondary metabolites in medicinal plants under UV-B stress. J. Photochem. Photobiol. B, Biol. 193, 51-88.

Taquichiri, M., Ayarde, R., Gutierrez, P., Bustos, A.-S., Paredes, C., Callisaya, J. C., Surco, J. C., Palenque, E.R., Ghezzi, F., Alvarado, J.A. \& Peñarrieta, J.M., 2014. High levels of resveratrol in grapes cultivated at high altitude valleys in Bolivia. Int. J. Fruit Sci. 14(3), 311-326.

Teixeira, A., Eiras-Dias, J., Castellarin, S.D. \& Gerós, H., 2013. Berry phenolics of grapevine under challenging environments. Int. J. Mol. Sci. 14(9), 18711-18739.

Thompson, L.G., Mosley-Thompson, E. \& Arnao, B. M., 1984. El NiñoSouthern Oscillation events recorded in the stratigraphy of the tropical Quelccaya ice cap, Peru. Science, 226(4670), 50-53. 
Turner, K.L. \& Davidson-Hunt, I.J., 2016. Tensions and synergies in the Central Valley of Tarija, Bolivia. commercial viticulture and agrobiodiversity in smallholder farming systems. Agroecol. Sustain. Food Syst. 40(6), 518552.

Versari, A., Paola Parpinello, G., Battista Tornielli, G., Ferrarini, R. \& Giulivo, C., 2001. Stilbene compounds and stilbene synthase expression during ripening, wilting, and UV treatment in grape cv. Corvina. J. Agric. Food Chem. 49(11), 5531-5536.

WHO., 2016. Radiation. Ultraviolet (UV) radiation. World Health Organization. https.//www.who.int/news-room/q-a-detail/radiationultraviolet-(uv)

Wines of Bolivia., 2020. Wines of Bolivia. https.//www.winesofbolivia. com/?lang=es

Zamuriano, M., Martynov, A., Panziera, L. \& Brönnimann, S., 2019. Characteristics of a hailstorm over the Andean La Paz Valley. Nat. Hazards and Earth Sys. Scie. 27, 1-21.
Zaratti, F., Forno, R.N., García Fuentes, J. \& Andrade, M.F., 2003 Erythemally weighted UV variations at two high-altitude locations. J. Geophys. Res. Atmos. 108(D9), 4263.

Zhang, E., Chai, F., Zhang, H., Li, S., Liang, Z. \& Fan, P., 2017. Effects of sunlight exclusion on the profiles of monoterpene biosynthesis and accumulation in grape exocarp and mesocarp. Food Chem. 237, 379-389.

Zhang, Z.Z., Che, X.N., Pan, Q.H., Li, X.X. \& Duan, C.Q., 2013. Transcriptional activation of flavan-3-ols biosynthesis in grape berries by UV irradiation depending on developmental stage. Plant Sci. 208, 64-74.

Zhu, Y., 2017. The effects of UV-B and water deficit on grape amino acids and wine aroma compounds. Doctoral Thesis, Lincoln University. 